\title{
COVID-19 compassion in self-isolating old age: looking forward from family to regional and global concerns
}

\author{
Ian Douglas ${ }^{1}$ (I)
}

Received: 17 May 2020 / Accepted: 10 June 2020

(C) The Author(s) 2020

\begin{abstract}
Self-isolating with my wife, I feel gratitude and compassion for all those supporting us, particularly those who regularly deliver our food and our immediate family members who check on us frequently. My compassion goes out to those on the "frontline", particularly my niece and her daughter who are both nurses in a major hospital and who developed and recovered from COVID-19 symptoms. More broadly, I recognise that there are many communities that have had to cope with both geophysical and socio-politically created disasters while facing the COVID-19 pandemic, among then some young women bee-keepers in Uganda. In the UK context, I have great concern that severe funding cuts for regional and local public health services and disaster planning handicapped the country's response to coronavirus and may have been a factor in the UK's high coronavirus death rate. I see both positive and negative changes in air pollution and urban nature in our towns and cities, but also am concerned that we collectively may lose sight of the greater crises of climate change and species extinction. We have to work for a better future by taking forward the opportunities and lessons from our reactions to the pandemic. This leads to compassion for the yet unborn, our grandchildren's children, who might enter a less habitable, more unequal less collaborative world than the imperfect one we now enjoy.
\end{abstract}

Keywords Compassion $\cdot$ Family $\cdot$ Nurses $\cdot$ Multiple disasters $\cdot$ Emergency planning $\cdot$ Regional authorities

\section{Introduction}

As a self-isolating octogenarian, my compassion goes to all the people who have enabled my wife and I to stay in our comfortable suburban home with its large 0.3 ha garden in Greater Manchester, UK, since 14 March 2020. I realise that we are far more fortunate than most people our age. In this essay, I consider my immediate personal reactions to the COVID-19 lockdown and the changes in the daily lives of my wife and I. I discuss how my family has been affected and how we now maintain contacts with our son and daughter. I then consider how the situation has revealed the consequences of the virtual elimination of any kind of public welfare and disaster preparedness at regional levels between central government and local authorities in England, UK. Drawing on my various past experiences (Douglas

Ian Douglas

ian.douglas@manchester.ac.uk

1 School of Environment, Education and Development, University of Manchester, 21 Taunton Road,

Sale, Cheshire M33 5DD, UK
1979, 2020; Douglas et al. 2010), I express concerns for vulnerable communities in multiple disaster situations and discuss how the changes happening in urban nature and the urban environment might be both beneficial and potentially problematic. I conclude by expressing the need to apply the concentration and coordination of the present campaign on COVI-19 to the potentially even more life-threatening climate emergency and associated extinction disaster.

\section{The personal situation and reaction}

While I recognise that compassion pushes us to understand "how we have structured the world, and to ask how we can structure it better, not because we may suffer but because others are suffering and that is not how the world should be" (Galea 2020, p. 1), I begin with my personal situation. I feel somewhat guilty that because of my age and a recent illness, I am not able to do as much for others as I would wish. I share the Dalai Lama's compassionate view that the social solution to the pandemic lies in our interdependence 
and the resulting happiness that comes from helping others (Seltzer 2020).

My immediate family members have seen that we have food and are well. More distant cousins have telephoned to check our welfare. Neighbours we had not previously met have asked if we need help. A wide variety of delivery drivers have brought milk, food, household goods, medicines, newspapers and books to the house: our days are marked by the particular items we expect to be delivered. Normally our son and daughter each bring food, and sometimes something special such as homemade cake or biscuits, that enliven our diet. There are telephone conversations with family and friends about the various delivery services for food. Instead of going to the shops, we have food from new sources: our milk delivery company which has interesting food from local suppliers; a major online grocery via our daughter; and from a local Italian restaurant chain. The geography of our retail experience has shifted. However, we feel that all of them are taking great care to deliver what we need in a safe and reliable manner.

\subsection{Novel ways of communicating}

The internet has become an essential part of our health care and shopping. I use "AskmyGP", a website by which I can send a message, sometimes with a photograph, to the local GP practice and receive an email, or a phone call, within a few hours. I had a specialist hospital appointment by telephone. I can order medicines online, and usually they are delivered by the pharmacy. All my contacts with these busy healthcare people have been excellent.

I have become used to Zoom meetings, both with the family and with the boards or members of organisations that I work with (the Commonwealth Human Ecology Council, Human Ecology Foundation, Manchester Geographical Society and UK Urban Ecology Forum). Two of the meetings involved members from Australia and New Zealand who seldom have the opportunity to express their views in person. For me, it is relief not to have to spend all day travelling to London and back for a meeting lasting $2 \mathrm{~h}$ or less.

Although my day-to-day life is relatively little changed by the pandemic, because my wife and I spend most of our days at home, we have had to cancel holidays and we miss having Sunday meals with our children and grandchildren and our occasional meals out at local restaurants. We are grateful to everyone involved in meeting the needs of people like us who are not leaving their homes.

\subsection{Implications for family members}

I feel compassion for those on the "frontline" of health and social care. My brother has lived in Brussels, Belgium, since 1962. His elder daughter is a senior nurse in a major hospital there. Her own daughter is also working as a newly qualified nurse in the same hospital. Both of them came home from the hospital with a loss of their sense of smell and feeling tired. They had mild COVID-19 symptoms, from which thankfully, they both recovered and returned to work. My niece's husband also became ill with COVID-19, but he too recovered. My niece had to have a further COVID-19 test but was able to continue working and in mid-May 2020 showed no COVID-19 symptoms. Another family member is caught up in plans to move house, having a place they want to move to, but being unable to progress the sale of their own house because of the social distancing problems.

\section{Emergency planning structures at the regional level}

\subsection{Past austerity measures affecting disaster response}

I also feel compassion for everyone who has been affected by the severe cuts in funding from central government that our local governments suffered (since 2010 in the UK), particularly those that have led to the diminution of local public health expertise. The losses extend to many metropolitan and regional strategic response and emergency planning bodies. In Greater Manchester, there used to be a strong Public Health team in each of the ten local councils and a fully staffed Greater Manchester Emergency Planning Unit (Table 1). The regional strategic health authorities that coordinated health services across local authorities and health authorities underwent many changes after 1974, finally being removed from the NHS system in 2013 (Table 2).

Between 2013 and 2019 Public Health England, the body responsible for protecting the public from infectious diseases and environmental hazards, suffered a $40 \%$ cut in funding in real terms. The annual grant from the UK central government to local authorities for public health activities has been cut by $27.5 \%$ in real terms since 2015-2016 (Lawrence et al. 2020). Many considered that the combination of reorganisation and structural change has severely weakened England's pandemic preparedness. I feel compassion for those who suffered from these impacts on the ability of the UK to react swiftly to declare a lockdown, get supplies into all appropriate settings and to be ready to assist more effectively in the sectors of cities that experienced public health workers knew to have high levels of ill health, inadequate housing, poverty and unemployment. For Greater Manchester, these issues are well understood (Robson 2016). The compassion, which leads us to say that the world is not how it should be, demands that we must find ways of helping people in such areas to avoid the higher national average infection rates they are experiencing in the COVID-19 pandemic. 
Table 1 Agencies responsible for emergency planning in Greater Manchester since 1974

\begin{tabular}{lll}
\hline Dates & Name and origin of organisation and relevant Act or Order & Territory of responsibility \\
\hline $1974-1986$ & Greater Manchester County Council & Greater Manchester \\
$1986-1993$ & Emergency Planning Unit at Greater Manchester Fire and Civil Defence Authority & Greater Manchester \\
$1993-2004$ & $\begin{array}{l}\text { Six Districts of Greater Manchester had an agency agreement with the Fire and Emergency } \\
\text { Planning Unit of AGMA (Association of Greater Manchester Authorities) }\end{array}$ & \\
2004 onwards & $\begin{array}{l}\text { Greater Manchester Resilience Forum } \\
\text { (Civil Contingencies Act, 2004) }\end{array}$ & Greater Manchester \\
2011 onwards & Civil Contingencies and Resilience Unit (CCRU) of AGMA & Greater Manchester \\
2014 onwards & All 10 Greater Manchester Districts make a political commitment to the Disaster Risk & Greater Manchester \\
& Reduction campaign of the United Nations International Strategy for Disaster Reduction & \\
& (UNISDR) &
\end{tabular}

Table 2 Changes over 75 years in the regional health strategic planning organisations for Greater Manchester

\begin{tabular}{|c|c|c|}
\hline Dates & Name and origin of organisation and relevant Act or Order & Territory of responsibility \\
\hline 1947-1974 & $\begin{array}{l}\text { Manchester Regional Hospital Board (National Health Service } \\
\text { Act, 1946) }\end{array}$ & $\begin{array}{l}\text { Chester, parts of Lancashire and south Cumbria, NW Derbyshire, } \\
\text { Greater Manchester }\end{array}$ \\
\hline 1974-1994 & $\begin{array}{l}\text { North-Western Regional Health Authority (National Health } \\
\text { Service Reorganisation Act 1973) }\end{array}$ & Lancashire, Greater Manchester, Glossop \\
\hline 1994-2002 & $\begin{array}{l}\text { North West (Mersey and North West) Health Authority [The } \\
\text { National Health Service (Determination of Districts) Order } \\
\text { 1994] }\end{array}$ & $\begin{array}{l}\text { Cheshire, Greater Manchester, Merseyside, south Cumbria and } \\
\text { Glossop }\end{array}$ \\
\hline 2002-2006 & $\begin{array}{l}\text { Greater Manchester Strategic Health Authority (Health and } \\
\text { Social Care Act 2001) }\end{array}$ & Greater Manchester and Glossop \\
\hline 2006-2013 & $\begin{array}{l}\text { NW England Strategic Health Authority [The Health Authori- } \\
\text { ties (Establishment and Abolition) (England) Amendment } \\
\text { Order 2004] }\end{array}$ & All of North West England \\
\hline 2013 & $\begin{array}{l}\text { Strategic Health Authorities abolished (Health and Social Care } \\
\text { Act 2012) }\end{array}$ & No regional authority of any kind subsequently \\
\hline 2017 & $\begin{array}{l}\text { Conferral of certain public health functions of local authori- } \\
\text { ties on the Greater Manchester Combined Authority ("the } \\
\text { GMCA"). [Greater Manchester Combined Authority (Public } \\
\text { Health Functions) Order } 2017 \text { (The Public Health Order)] }\end{array}$ & $\begin{array}{l}\text { Move towards a metropolitan regional approach combining } \\
\text { health and social care }\end{array}$ \\
\hline
\end{tabular}

\subsection{Organisational continuity}

In Greater Manchester, for example, consistency in strategic planning coming from organisational continuity brought measurable benefits to local communities in such terms as responses to HIV/AIDS, diabetes and mental health in individual local authority district within the metropolitan area (Snow 2016). Many public health officers remained in post when the responsibilities for public health were moved from NHS local bodies to local municipal government authorities in 2012. Where this did not happen, constant reorganisation and shifts in policy meant that some local services deteriorated (Snow 2016). Nevertheless, the UK response to COVID-19 does not appear, in its initial stages at least, to have used local knowledge, to have identified particular pressure points and areas of high vulnerability. Despite reorganisation, local public health skills, understanding and experience in tracking and tracing infectious diseases could have been used.

Failure to secure, retain and use local knowledge is a major health and environmental issue. In urban environmental terms, from my experience with sewers, derelict land and waste disposal, the people who know where private and public sewers connected, where noxious chemicals had been stored and processed within a factory, and where waste materials, such as tar and contaminated rubble, had been dumped, are no longer in post and their knowledge is lost. I feel compassion for those who have been affected by delays and disruptions through lack of such local understanding and loss of long familiarity within and about the organisations, people and problems of particular regions and urban areas. 


\subsection{City region disaster planning and response reorganisation}

Regionalisation of emergency services co-ordination has its problems (Coaffee and Rogers 2008), but I see recent steps that seem to indicate that city region responsibilities may be redeveloping: emergency preparedness may be revived by the rolling programme of risk assessment set up by the Greater Manchester Local Resilience Forum after the 2004 UK Civil Contingencies Act (Oldham 2018). The Forum's assessment includes preparations for pandemic influenza (Fig. 1) which may have come into play in the COVID-19 pandemic.

Big questions remain as to how well we learn lessons from past events. Awareness and concern about specific hazards decrease exponentially the longer the time span since an event has occurred. However, recommendations on the lessons that ought to have been learnt abound. The swine flu outbreak of 2009-2010 was declared a pandemic, but the 474 deaths across the UK that it caused fell far short of the worst-case scenario of 750,000 deaths. Some key issues emerging from the event (Boyd et al. 2012) were:

- The overly top-down national response;

- Importance of good coordination and collaboration between agencies at local level and between local organisations and regional bodies;
- Local flexibility to take account of local patterns of spread of infection;

- Clarity about which decisions will be taken locally, regionally and nationally;

- More use of social networking and digital technology to reach specific sections of the public.

\section{People facing multiple hazards}

\subsection{Double disaster threat for a project in Uganda}

I feel compassion for people working on projects in which the organisations I support are involved. In particular, I have endeavoured to support a pilot project which is training young unmarried mothers in bee-keeping in eastern Uganda. Since early March 2020, lockdown has prevented our local project supervisor from delivering the planned training sessions to the young women. Experts have not been able to visit the new hives to see how well they have been colonised by the bees. We have arranged some extra funding to support such visits as soon as travel from one village to another is permitted.

I was also concerned that there might be a double disaster facing the young women when Aljazeera reported that farmers in Uganda were facing a fresh onslaught of desert locusts in the first week of April 2020. In addition to the damage the insects might do, COVID-19 control measures mean

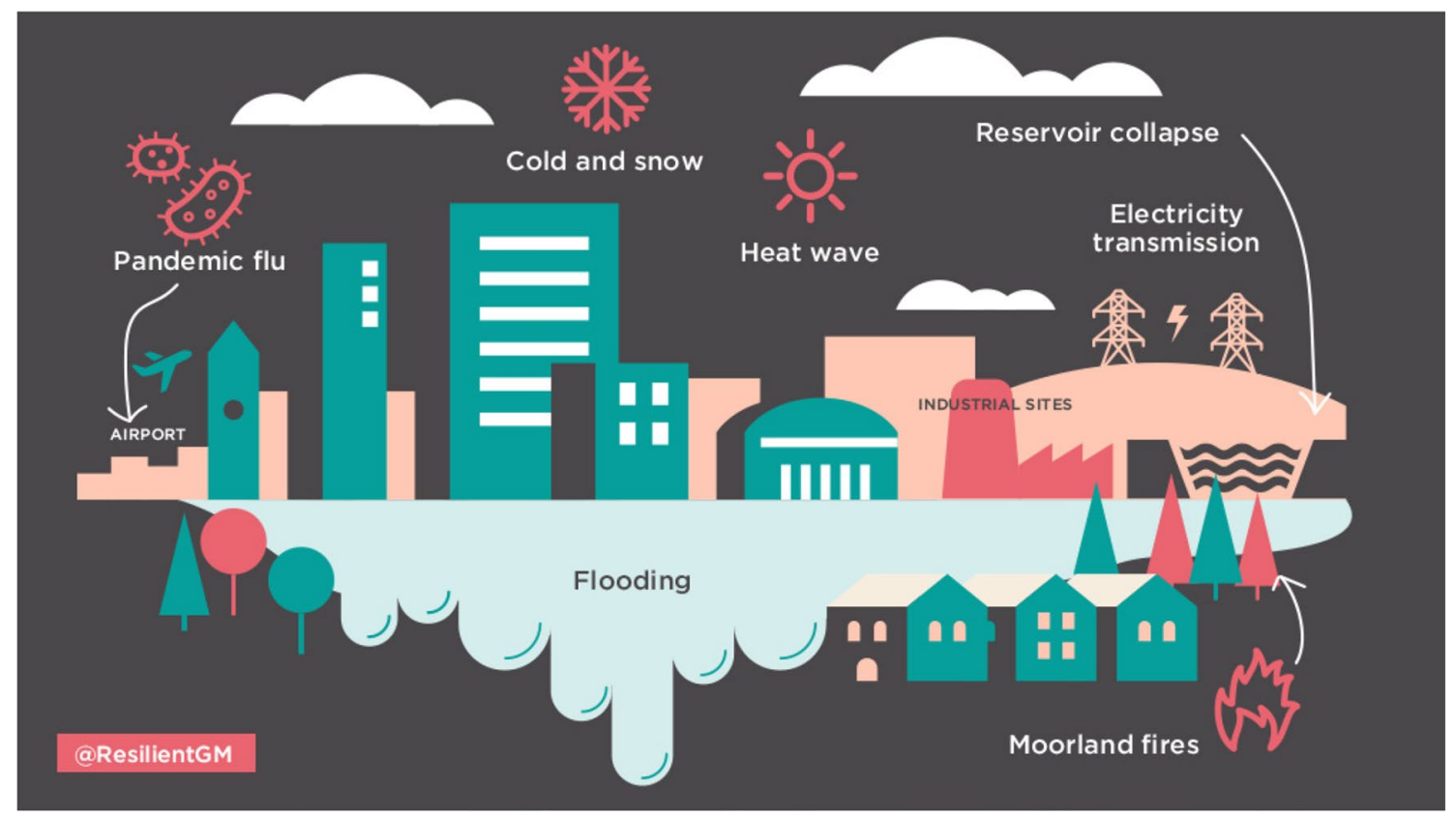

Fig. 1 Emergencies, including pandemic flu, envisaged by the Greater Manchester Resilience Forum (https://www.100resilientcities.org/ prepared-future-greater-manchesters-journey-emergency-preparedne ss-resilience/) (reproduced by permission of the Greater Manchester Combined Authority) 
that there were few staff available to implement field control measures. Fortunately, I was informed that the locusts had not invaded our project area. However, my anxiety continues as there is talk of a third generation of locusts in Uganda in June and July 2020 that would coincide with the start of the mid-year harvest.

\subsection{Cyclones, hurricanes and typhoons during the COVID-19 pandemic}

"Normal" disasters are still occurring, but there is less space for them in the news media. Double disasters have happened in the western Atlantic, northern Indian and the south-western Pacific Oceans, where coastal communities already threatened by rising sea levels have been hit by tropical cyclones (hurricanes or typhoons). Many workers who had lost their jobs and who returned to their homes around the Bay of Bengal were hit by Cyclone Amphan on 19-21 May 2020, losing their homes, power and telecommunications connections, driving some families into destitution. On May 22 Hurricane Aaron hit the Bahamas, with winds of approximately $250 \mathrm{~km} \mathrm{~h}^{-1}$, killing 208 people and causing over $\$ 7.5$ billion in damage. On May 24th Tropical Cyclone Mangga brought power outages and some damage to West Australian coastal communities from the Kimberley in the north to Perth.

In early April 2020, when many wealthy nations were individualistically in lockdown with closed borders, Tropical Cyclone Harold first damaged the Solomon Islands, then lashed the South Pacific island of Vanuatu, ripping off roofs and downing telecommunications, before moving towards Fiji and Tonga. The powerful cyclone made landfall in Sana province, an island north of Vanuatu's capital Port Vila, with winds reaching up to $235 \mathrm{~km}$ an hour that flattened some buildings and left others roofless. This cyclone then levelled buildings and caused dangerous flooding across Fiji's largest island of Viti Levu, before strengthening as it moved on to Tonga as a category 5 superstorm. Such tropical cyclones in the pacific can devastate the entire landscape of small islands.

When category 5 cyclone Harold struck Vanuatu in early April 2020, the country still had no confirmed cases of COVID-19. The islands had been closed to international travellers and had taken social distancing measures. In preparation for the pandemic, the UN had provided Vanuatu tents to treat patients and community outreach training. However, the stringent lockdown measures meant that the islanders had little outside help in dealing with the widespread devastation caused by the cyclone. Fortunately, their primary strategy to keep COVID-19 out largely worked. New Zealanders I collaborate with feel particular compassion for those in such situations for not only are they regularly hit by cyclones, but they are also already suffering by the rising sea levels and increased storminess caused by global heating and the consequent climate emergency. The islanders are not major contributors to the causes of climate change, but deserve our compassion because they are some of the most severely affected victims of its impacts.

\section{COVID-19 impacts of the urban environment and wildlife}

\subsection{Urban air pollution and the global climatic effects of the pandemic}

The impact of the COVID-19 lockdown on the climate is having both beneficial and harmful effects (Table 3). I am enjoying the clearer, bluer skies and the reduced air pollution resulting from decreased traffic and industrial emissions, but am concerned that national and international attention to the climate emergency has fallen. The COP 26 talks have been delayed until next year. Meanwhile, air pollution levels in China had rebounded to pre-pandemic levels by early June 2020 (Carrington 2020). The increasingly urgent need for a new international agreement on greenhouse gas emissions is being temporarily ignored, while the policing of illegal burning, waste disposal and other breaches of environmental legislation has been weakened.

Back in the cities, there are conflicting stories about urban nature (Table 3). Those people at home lucky enough to have their own gardens or well-vegetated parks in which to walk have heard more bird song and seen animals wandering on to quieter streets and greater numbers. On the other hand, crucial work in removing noxious weeds, like Himalayan Balsam, may be greatly reduced in the UK where nearly 40,000 Wildlife Trust volunteers have to stay at home. Nature conservation organisations thus may not be able work on nature reserves, have little help with administration, and no outreach activities. If industrial firms close, or are forced to shut because of bankruptcies, maintenance of installations may cease and the risk of chemical and gas leaks will increase (Shirley 2020).

\section{How could our COVID-19 experiences help us change our behaviour to cope with the climate crisis?}

The way governments have responded to the COVID-19 emergency shows that it is possible to change human behaviour. The amount of outdoor exercise now being taken by walking in the local area and using urban greenspaces gives me hope that in future people will recognise the health and psychological benefits of contact with nature in towns and cities, expressed in recent books (Clare 2020). However, I 


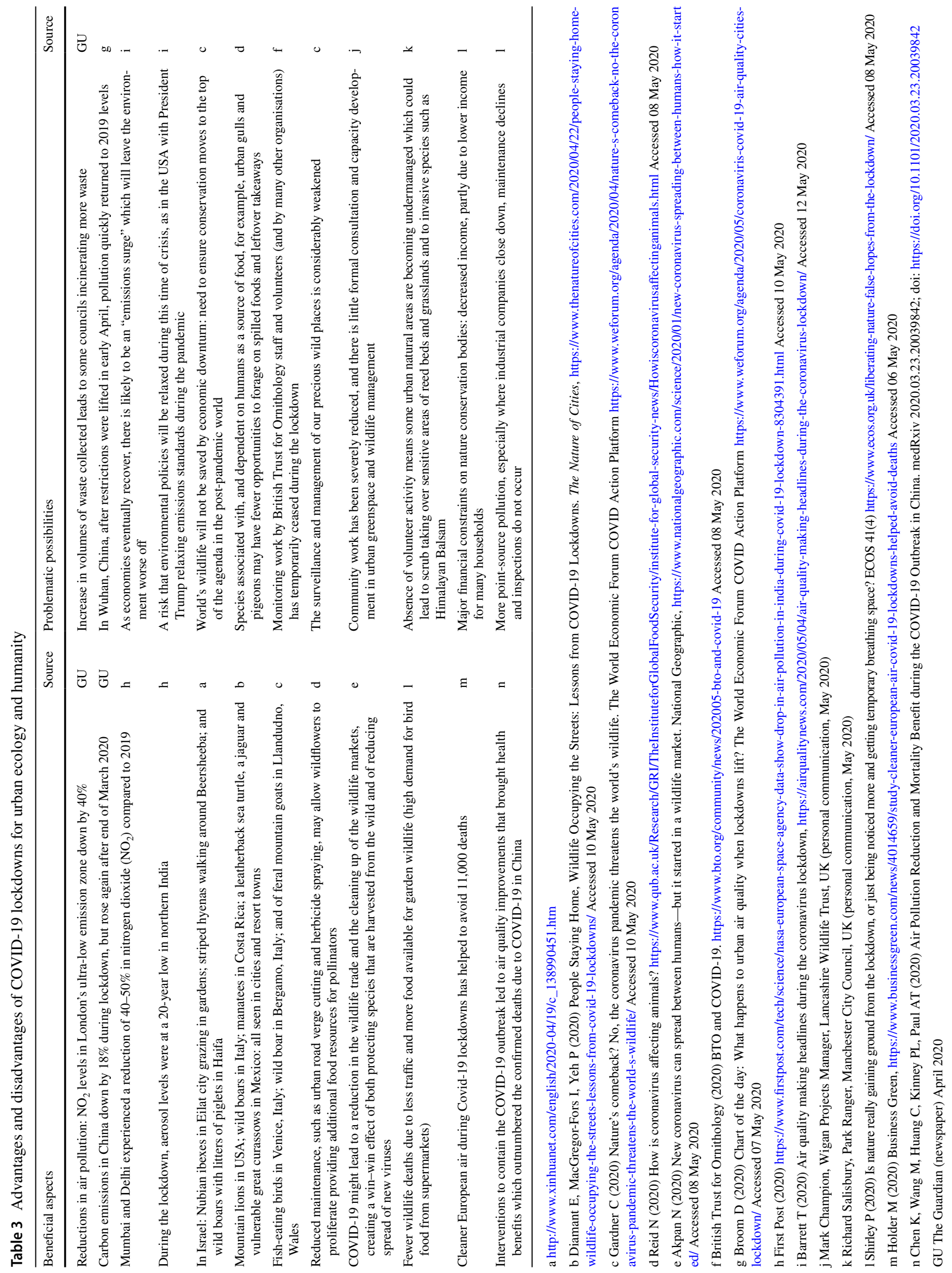


have compassion for those who write to newspapers urging acknowledgement of our collective failure to respond to climate change and identify its consequences. I also accept the need for all of us, at the personal, local, regional, national and global levels, to accelerate the mitigation and adaptation so desperately needed now to cope with the climate crisis that threatens a greater tragedy than coronavirus might have been.

We also need to build on the concerns shown among neighbours and the elements of national solidarity encouraged by politicians, to look beyond our own national concerns: the pandemic is a global phenomenon, just as the climate crisis and the Anthropocene mass extinction are (Scharf, 2020). I feel compassion for those who like me have witnessed enormous global changes in their own life times during which the pace of development, with its competition for the tallest, biggest and most profitable, has taken our eyes off the really important goal of sustaining a world that our grandchildren's children will be able to enjoy. I have compassion for the yet unborn, who may suffer if we are not smart enough, not efficient enough, not caring enough, not serious enough about the ecosystems that support us, and all the biota with which we share the planet, to ensure this habitable world remains so for future generations. It may take a long time to "get back to normal", but should we be trying to move on to a new situation of continuing compassion, care for others and care for our environment?

Open Access This article is licensed under a Creative Commons Attribution 4.0 International License, which permits use, sharing, adaptation, distribution and reproduction in any medium or format, as long as you give appropriate credit to the original author(s) and the source, provide a link to the Creative Commons licence, and indicate if changes were made. The images or other third party material in this article are included in the article's Creative Commons licence, unless indicated otherwise in a credit line to the material. If material is not included in the article's Creative Commons licence and your intended use is not permitted by statutory regulation or exceeds the permitted use, you will need to obtain permission directly from the copyright holder. To view a copy of this licence, visit http://creativecommons.org/licenses/by/4.0/.

\section{References}

Boyd A, Chambers N, French S, King R, Shaw D, Whitehead A (2012) A scoping study of emergency planning and management in health care: What further research is needed? NHS National Institute for Health Research. http://www.netscc.ac.uk/hsdr/files/project/SDO_ FR_09-1005-01_V01.pdf. Accessed 12 May 2020

Carrington D (2020) China; air pollution rebounds to pre-virus levels. The Guardian, 4 June 2020 p 24
Clare H (2020) Nature's cure. Financial Times FT Weekend, Life \& Arts 9 May 2020, p 7

Coaffee J, Rogers P (2008) Rebordering the city for new: from counterterrorism to community resilience. Space Polity 12(1):101-118. https://doi.org/10.1080/13562570801969556

Douglas I (1979) Flooding in Australia: a review. In: Heathcote RL, Thom BG (eds) Natural hazards in Australia. Australian Academy of Science, Canberra, pp 143-163

Douglas I (2020) Scholar in the SEPR spotlight: Ian Douglas. Soc Ecol Pract Res. https://doi.org/10.1007/s42532-020-00051-6

Douglas I, Garvin S, Lawson N, Richards J, Tippett J, White I (2010) Urban pluvial flooding: a qualitative study of cause, effect and non-structural mitigation. J Flood Risk Manag 3:112-125

Galea S (2020) Compassion in a time of COVID-19. Lancet. https:// doi.org/10.1016/S0140-6736(20)31202-2. Accessed 03 June 2020

Lawrence F, Pegg D, Garside J, Conn D, Carrel S, Davies H (2020) From austerity to COVID-19: How a decade of NHS cuts and privatisation left the UK exposed to a pandemic. Guardian 1 June 2020, 14-17

Oldham K (2018) Prepared for the future: Greater Manchester's journey from emergency preparedness to resilience. 100 resilient cities. https://www.100resilientcities.org/prepared-future-great er-manchesters-journey-emergency-preparedness-resilience/. Accessed 12 May 2020

Robson B (2016) The resurgent entrepreneurial city. In: Kidd A, Wyke $\mathrm{T}$ (eds) Manchester: making the modern city. Liverpool University Press, Liverpool, pp 346-396

Scharf CA (2020) Life inside the extinction: these are startling times, but there's a way out. Scientific American Blog https://blogs.scien tificamerican.com/life-unbounded/life-inside-the-extinction/. Accessed 11 May 2020

Seltzer LF (2020) The Dalai Lama on COVID-19: compassion as the best weapon? Psychology Today. https://www.psychologytoday. com/us/blog/evolution-the-self/202004/the-dalai-lama-covid-19compassion-the-best-weapon. Accessed 4 June 2020

Shirley $\mathrm{P}$ (2020) Is nature really gaining ground from the lockdown, or just being noticed more and getting temporary breathing space? ECOS 41(4). https://www.ecos.org.uk/liberating-nature-falsehopes-from-the-lockdown/. Accessed 10 May 2020

Snow SJ (2016) Health and Greater Manchester in historical perspective. Representation 51(4):439-452

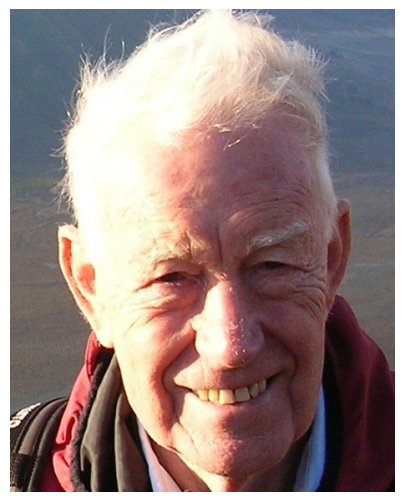

Ian Douglas studied at Oxford and the Australian National University specialising in tropical geomorphology, erosion and sedimentation. Concern about human environmental impacts led to urban geomorphology and eventually urban ecology. He was Professor at the University of New England, Australia 1972-1978 and since then at the University of Manchester UK. 